\title{
Efektivitas Model Pembelajaran Inkuiri Terbimbing untuk Meningkatkan Kemampuan Berpikir Kreatif Siswa SMA Pada Materi pada materi Momentum dan Impuls
}

\author{
Rini Asriani ${ }^{1 *}$, Abdul Hakim ${ }^{2}$, dan Shelly Efwinda ${ }^{3}$ \\ $1^{\star 2,3}$ Program Studi Pendidikan Fisika, FKIP, Universitas Mulawarman \\ JI. M. Yamin Samarinda, Kalimantan Timur, Indonesia \\ Email : ningasriani@gmail.com
}

\begin{abstract}
Abstrak
Penelitian ini bertujuan mengetahui keefektifan model pembelajaran inkuiri terbimbing untuk meningkatkan kemampuan berpikir kreatif siswa SMA pada materi momentum dan impuls. Penelitian ini merupakan jenis penelitian quasi eksperimen dengan desain static group pretest-posttest design. Teknik pengambilan sampel yang digunakan adalah purposive sampling. Populasi pada penelitian ini adalah seluruh siswa kelas X MIPA SMA Negeri 5 Samarinda tahun ajaran 2019/2020. Sampel penelitian ini adalah siswa kelas X MIPA 4 dan 5 yang masing-masing berjumlah 36 orang. Analisis data menggunakan uji $t$ independen $t$ test. Hasil analisis data menunjukkan terdapat perbedaan yang signifikan antara rata-rata kelas eksperimen dan kontrol dengan perolehan p-value sebesar 0,000 . Peningkatan kemampuan berpikir kreatif siswa pada kelas eksperimen diperoleh nilai rata-rata $\mathrm{N}$-Gain sebesar 0,49 dalam kategori sedang. Model inkuiri terbimbing untuk meningkatkan kemampuan berpikir kreatif siswa memiliki tingkat keefektifan yang tinggi dengan effect size sebesar 0,93.
\end{abstract}

Kata kunci: Inkuiri Terbimbing, Kemampuan Berpikir Kreatif, Momentum dan Impuls.

\begin{abstract}
This research aims to determine the effectiveness of guided instruction learning models to improve the creative thinking skills of high school students on momentum and impulse materials. The sampling technique used is purposive sampling. Population in this study is all students grade X MIPA SMA Negeri 5 Samarinda 2020/2021 with two classes as a sample; each class consists of 36 students. This research is a quasi research experiment with a static group pretest-posttest design. Analyze data using an independent t-test. The data analysis showed significant differences in students' creative thinking skills between experiment and control classes with a p-value gain of 0,000. Students' creative thinking skills in the experiment class obtained an average N-Gain score of 0.49 in the moderate category. The induction model guided to improve students' creative thinking skills has a high effectiveness with an effect size of 0.93 .
\end{abstract}

Keywords: Guided inquiry, creative thinking, Momentum and Impuls

\begin{tabular}{|c|c|c|}
\hline Article History: & $\begin{array}{l}\text { Received: } 27 \text { January } 2021 \\
\text { Accepted: } 10 \text { March } 2021\end{array}$ & $\begin{array}{l}\text { Revised : } 20 \text { Maret } 2021 \\
\text { Published: } 30 \text { April } 2021\end{array}$ \\
\hline
\end{tabular}

How to cite: Asriani, R., Hakim, A., Efwinda, S. (2021). Keefektifan Model Pembelajaran Inkuiri Terbimbing untuk Meningkatkan Kemampuan Berpikir Kreatif Siswa SMA pada Materi Momentum dan Impuls 1(1). pp 34-43. Retrieved from http://jurnal.fkip.unmul.ac.id/index.php/JLPF

Copyright @ April 2021, Jurnal Literasi Pendidikan Fisika 
Efektifitas Model Pembelajaran...

\section{PENDAHULUAN}

Indonesia adalah negara berkembang yang masih mempunyai masalah dalam pendidikan. Salah satu masalah dalam dunia pendidikan yang merata adalah kurang berdayanya suatu lembaga pendidikan untuk melakukan proses pendidikan sehingga terjadi kesenjangan kualitas pendidikan antara di kota dan daerah-daerah terpencil. Masih banyak sekolah di daerah terpencil yang belum medapat perhatian khusus dari pemerintah Indonesia. Padahal tujuan utama dari pendidikan untuk meningkatkan kualitas sumber daya manusia. Pendidikan adalah hal yang penting untuk kemajuan suatu bangsa, pendidikan merupakan proses melahirkan generasi penerus yang berkualitas. Berdasarkan Undang-Undang tentang sistem pendidikan Nasional Nomor 20 tahun 2003 pada bab II pasal 3 disebutkan bahwa pendidikan nasional berfungsi mengembangkan kemampuan dan membentuk watak serta peradaban bangsa yang bermartabat dalam rangka mencerdaskan kehidupan bangsa, bertujuan untuk berkembangnya potensi peserta didik agar menjadi manusia yang beriman dan bertaqwa kepada Tuhan Yang Maha Esa, berakhlak mulia, sehat, berilmu,cakap, kreatif, mandiri, dan menjadi warga Negara yang demokratis serta bertanggung jawab (Depdiknas, 2005)

Menurut survey Political and Economic Risk Consultant (PERC), kualitas pendidikan di Indonesia berada pada urutan ke 12 dari 12 Negara di Asia. Posisi Indonesia berada dibawah Vietnam. Data yang dilaporkan The World Economic Forum Swedia (2000), Indonesia memiliki daya saing yang rendah, yaitu hanya menduduki urutan ke 37 dari 57 Negara yang di survey di dunia. Hasil studi TIMSS (Trends In International Mathematics and Science Study) menunjukkan siswa Indonesia berada pada peringkat amat rendah dalam beberapa hal seperti memahami informasi yang kompleks, memahami teori, analisis dan pemecahan masalah, serta dalam hal investigasi. ( Purwananti, 2016).

Pada abad 21 bangsa Indonesia menghadapi tantangan global yang sangat banyak. Kompetensi yang dibutuhkan pada abad 21 menunjukkan bahwa pendidikan pada abad 21 akan didominasi oleh pendidikan yang berbasis ICT. Inilah yang menjadi tantangan pembelajaran abad 21 , yaitu kehadiran ICT dalam dunia pendidikan. Siswa harus memiliki standar performasi yang tinggi serta penguasaan materi pembelajaran secara mendalam sehingga mampu menghadapi tantangan zaman yang kompleks. National Education Association (n.d) telah mengidentifikasi keterampilan abad ke 21 sebagai keterampilan "The 4Cs". Peserta didik perlu mengembangkan keterampilan the 4Cs, meliputi berpikir kritis, kreativitas, komunikasi, dan kolaborasi. Keempat keterampilan tersebut mampu membuat siswa beradaptasi dan berkembang pada abad 21. Keterampilan ini juga bisa menjadi landasan dasar untuk merancang pembelajaran yang sesuai agar siswa bisa beradaptasi di lingkungan abad 21 . Kebutuhankebutuhan dalam kehidupan di abad 21 dalam dunia pendidikan menuntut adanya pergeseran tujuan pendidikan dengan menyiapkan peserta didik menghadapi dunia kerja yang semakin ketat. (Redhana, 2019)

Masalah pendidikan sering kita temukan di berbagai daerah, baik secara langsung maupun melalui media elektronik seperti televisi, handphone, dan lain sebagainya. Seharusnya seluruh anak Indonesia mendapat hak pendidikan seperti dalam UUD 1945 pada alinea ke 4 yang berbunyi " mencerdaskan kehidupan bangsa", dengan demikian pendidikan merupakan faktor utama dalam kehidupan. Kecendrungan rendahnya mutu pendidikan di Indonesia salah satunya karena adanya proses belajar yang tidak efektif yang mengakibatkan ketidakmampuan guru dalam menjelaskan materi pelajaran, fasilitas pendidikan minim, dan juga ketidakmampuan siswa menyerap pelajaran. Untuk mengatasi permasalahan dalam pembelajaran, diperlukan solusi untuk memperbaiki pembelajaran yang membuat peserta didik aktif dan paham materi pelajaran, serta berupaya menumbuhkan kemampuan berpikir dan sikap kreatif, salah satunya model pembelajaran yang tepat yaitu model pembelajaran inkuiri terbimbing.

Inkuiri terbimbing yaitu pendekatan inkuiri dimana guru membimbing siswa untuk melakukan kegiatan dengan memberi pertanyaan awal dan mengarahkannya pada suatu diskusi. Guru mempunyai peran aktif dalam menentukan permasalahan dan tahap-tahap pemecahannya. Dengan

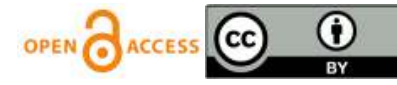


Efektifitas Model Pembelajaran...

pendekatan ini, siswa yang belajar lebih berorientasi pada bimbingan dan petunjuk dari guru sehingga siswa dapat memahami konsep-konsep pelajaran. Pada pendekatan ini, siswa akan dihadapkan pada tugas-tugas yang relevan untuk diselesaikan baik melalui diskusi keolompok maupun secara individual agar mampu menyelesaikan masalah dan menarik suatu kesimpulan secara mandiri (Nur, 2014:190). Inkuiri terbimbing berorientasi pada aktivitas kelas yang berpusat pada siswa dan memungkinkan siswa belajar memanfaatkan berbagai sumber belajar yang tidak hanya menjadikan guru sebagai sumber belajar. Siswa secara aktif akan terlibat dalam proses mentalnya melalui kegiatan pengamatan, pengukuran, dan pengumpulan data untuk menarik suatu kesimpulan. Dalam pembelajaran inkuiri terbimbing siswa secara aktif dalam proses pembelajaran yaitu melalui perencanaan, peaksanaan, sampai proses evaluasi. Dengan menerapkan pembelajaran berbasis inkuri akan memacu keingintahuan siswa dalam menemukan hal-hal yang ingin diketahui siswa (Nurdyansyah, 2016). Menurut Amijaya (2018) model inkuiri terbimbing dapat mendorong peserta didik secara aktif untuk menggali pengetahuannya sendiri sehingga peserta didik dapat menjadi pribadi yang mandiri, aktif serta terampil dalam memecahkan masalah berdasarkan informasi dan pengetahuan yang didapatkan. Kegiatan inkuiri bukan sekedar melaksanakan kegiatan eksperimen tetapi lebih menekankan pada imajinasi dan kemampuan siswa untuk menemukan bukti empiris (Wenning, 2007)

Wenning (2011) mengembangkan model pembelajaran inkuiri bertingkat yang dinamakan levels of inquiry model yang terdiri dari enam tingkatan inkuiri, diantaranya discovery learning, interactive demonstration, inquiry lesson, inquiry lab (3 type-guided, bounded, and free) dan hypothetical (2 typepure and applied). Tingkatan inkuiri tersebut diurutkan berdasarkan kemampuan intelektual siswa dan pihak pengontrol. Keterampilan berpikir yang sangat penting yaitu keterampilan berpikir kreatif. Berpikir kreatif merupakan proses berpikir dalam menentukan hubungan-hubungan baru antara berbagai hal,.Johnson (2002) dalam Lutfiyah (2019) mengemukakan berpikir kreatif diartikan sebagai suatu kegiatan mental yang digunakan seorang untuk membangun ide atau gagasan yang baru secara fasih dan fleksibel. Keterampilan berpikir kreatif yaitu keterampilan individu dalam menggunakan proses berpikirnya untuk menghasilkan gagasan yang baru, konstruktif berdasarkan konsep-konsep dan prinsip-prinsip yang rasional maupun persepsi dan intuisi individu. Secara umum proses berpikir mengikuti insting atau naluri secara bebas dalam mencari sesuatu yang berhubungan (berkaitan) dengan masalah yang ingin dipecahkan atau mencari kunci jawaban atas sesuatu yang di permasalahkan. Menurut Guilford dalam Suardipa (2019) indikator berpikir kreatif yakni: kelancaran (fluency) adalah kemampuan memproduksi banyak gagasan, keluwesan (flexibility) adalah kemampuan untuk mengajukan berbagai pendekatan atau jalan penyelesaian masalah, penguraian (elaboration) adalah kemampuan menguraikan sesuatu secara terperinci, dan keaslian (originality) adalah kemampuan untuk melahirkan gagasan atau ide sebagai hasil pemikiran sendiri. Berpikir kreatif penting bagi siswa dalam membantu memecahkan masalah yang sering dihadapi dalam proses belajar. Kemampuan berpikir kreatif dapat dilakukan dengan proses pembelajaran yang menekankan pada keterlibatan siswa. Model pembelajaran siswa yang sesuai dengan ini salah satunnya adalah model pembelajaran inkuiri terbimbing. Model pembelajaran inkuiri terbimbing ini bertujuan mendorong siswa untuk berpartisipasi dan terlihat secara aktif dalam pembelajaran serta mampu membuat siswa menjadi lebih terampil.

Dalam penelitian ini, penulis mengacu pada beberapa penelitian terdahulu yang relevan dan dijadikan sebagai bahan telaah diantaranya penelitian yang dilakukan oleh Vlassi $\mathrm{M}$ dan Alexandra (2014) yang berjudul "The comparison between guided inquiry and traditional teaching method. A case study for the teaching of the structure of matter to 8th grade Greek students". Tujuan dari penelitian ini adalah untuk membandingkan metode inkuiri terbimbing dengan metode tradisional untuk pengajaran konsep yang merujuk pada struktur materi. hasil dari penelitian ini menyimpulkan bahwa pembelajaran dengan menggunakan metode inkuiri terbimbing lebih efektif dari pada menggunakan metode tradisional karena adanya perbedaan yang signifikan secara statistik dari kedua sampel dengan skor untuk kelompok kontrol sebesar 43,99\% (metode tradisional) dan 70,67\% (metode inkuiri terbimbing) untuk kelompok eksperimen. Penelitian relevan selanjutnya yang dilakukan oleh Serevina Vena, ddk

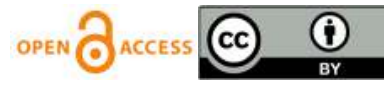


Efektifitas Model Pembelajaran...

(2018) yang berjudul "Improving creative thinking ability of class $X$ students public high school 59 Jakarta through guided inquiry learning model." Tujuan dari penelitian ini adalah untuk mengetahui apakah model pembelajaran inkuiri terbimbing dapat meningkatkan kemampuan berpikir kreatif siswa kelas X-1 SMA Negeri 59 Jakarta. Hasil penelitian menunjukkan skor kemampuan berpikir kreatif siswa diperoleh sebesar $52,00 \%$ untuk aspek kelancaran pada siklus 1 dan $60,57 \%$ pada siklus 2 . Aspek fleksibilitas meningkat dari $44,29 \%$ pada siklus 1 menjadi $55,71 \%$ pada siklus 2 , aspek orisinalitas meningkat dari $49,52 \%$ pada siklus 1 menjadi $59,05 \%$ pada siklus 2 , dan aspek elaborasi meningkat dari $45,71 \%$ pada siklus 1 menjadi $58,57 \%$ pada siklus 2 . Sehingga dapat disimpulkan bahwa model pembelajaran inkuiri terbimbing dapat meningkatkan kemampuan berpikir kreatif siswa dalam aspek kelancaran, fleksibilitas, orisinalitas dan elaborasi.

Berdasarkan hasil observasi melalui wawancara yang telah dilakukan di SMA Negeri 5 Samarinda, ternyata masih banyak peserta didik yang beranggapan bahwa fisika merupakan pelajaran yang sulit dan membosankan. Karena, selama proses pembelajaran terlalu banyak rumus yang dihafal dan penyelesaian permasalahan selalu dengan proses perhitungan. Model pembelajaran yang digunakan selalu dengan metode ceramah atau konvensional yang membuat peserta didik cenderung pasif dan selalu berpusat pada guru. Hingga saat ini ilmu fisika masih dinilai sebagai pelajaran yang sulit untuk dikuasai dan membosankan. Hal ini sangat membatasi ruang lingkup berpikir yang menyebabkan kemampuab berpikir kreatif peserta didik akan terbatas.

Berdasarkan permasalahan yang telah diuraikan diatas, perlu adanya pembelajaran yang membuat peserta didik aktif serta memberi kesempatan untuk menggunakan kemapuannya sendiri dalam melatih kemampuan berfikir kreatif agar lebih berkembang, demi tercapainya kurikulum yang sudah di tetapkan disekolah. Berkembangnya keterampilan peserta didik seperti mengamati, berkomunikasi dan menyimpulkan data merupkan salah satu wujud dari kemampuan berinkuiri serta kemampuan berfikir kreatif. Berdasarkan uraian diatas, maka penulis terdorong untuk melakukan penelitian tentang efektivitas model pembelajaran inkuiri terbimbing untuk meningkatkan kemampuan berpikir kreatif siswa SMA pada materi momentum dan impuls.

\section{METODE}

Jenis penelitian yang digunakan pada penelitian ini adalah jenis penelitian quasi eksperimen dengan desain penelitian The Static Group Pretest-Posttest Design (Fraenkel, 2012:270). Teknik pengambilan sampel dalam penelitian ini adalah purposive sampling, yaitu teknik penentuan sampel dengan pertimbangan tertentu. Teknik pengumpulan data yang digunakan dalam peneltian ini ialah teknik tes. Tes yang digunakan adalah tes tertulis kognitif yaitu pretest dan posttest. Dimana, soal pretest diberikan pada awal pembelajaran untuk mengetahui kemampuan awal siswa sebelum diterapkannya model pembelajaran inkuiri terbimbing sedangkan posttest diberikan pada akhir pembelajaran. Soal pretest dan posttest berupa soal essay sebanyak 10 soal yang mengacu pada indikator kemampuan berpikir kreatif yaitu berpikir lancar (fluency), berpikir luwes (flexibility), berpikir orisinil (originality), dan berpikir merinci (elaboration).

Tabel 1. Indikator Berpikir Kreatif

\begin{tabular}{|c|c|c|}
\hline No & Indikator & Perilaku \\
\hline 1 & $\begin{array}{l}\text { Kemampuan berpikir lancar } \\
\text { (Fluency) }\end{array}$ & $\begin{array}{l}\text { Mengajukan banyak pertanyaan, kemampuan } \\
\text { mengemukakan ide-ide yang serupa untuk memecahkan } \\
\text { suatu masalah. }\end{array}$ \\
\hline 2 & $\begin{array}{l}\text { Kemampuan berpikir luwes } \\
\text { (Flexibility). }\end{array}$ & $\begin{array}{l}\text { Memberikan bermacam-macam penafsiran (interpretasi) } \\
\text { terhadap suatu gambar. }\end{array}$ \\
\hline 3 & $\begin{array}{l}\text { Kemampuan berpikir orisinil } \\
\text { (Originality) }\end{array}$ & $\begin{array}{l}\text { Memberikan bermacam-macam penafsiran (interpretasi) } \\
\text { terhadap suatu masalah }\end{array}$ \\
\hline 4 & $\begin{array}{l}\text { Kemampuan } \\
\text { merinci (Elaboration) }\end{array}$ & $\begin{array}{l}\text { Mengembangkan atau memperkaya gagasan orang lain. } \\
\text { Menyusun langkah-langkah secara terperinci }\end{array}$ \\
\hline
\end{tabular}

(Yuliani, 2017: 51) 
Efektifitas Model Pembelajaran...

Teknik analisis data yang digunakan pada penelitian ini yaitu nilai rata-rata (mean) untuk mengetahui rata-rata nilai kemampuan berpikir kreatif. $\mathrm{N}$-Gain untuk mengetahui peningkatan kemampuan berpikir kreatif siswa. Kemudian dilakukan uji hipotesis (uji t indepen) untuk mengetahui perbedaan kemampuan berpikir kreatif siswa antara sebelum dan sesudah diterapkan model pembelajaran inkuiri. Teknik analisis data terakhir yang digunakan yaitu effect size untuk mengetahui efektivitas model pembelajaran inkuiri terbimbing, terhadap peningkatan kemampuan berpikir kreatif siswa.

\section{HASIL DAN PEMBAHASAN}

\section{HASIL}

Rata-rata hasil pretest peserta didik pada kelas eksperimen sebesar 30,56 sedangkan pada kelas kontrol sebesar 33,61. Untuk nilai rata-rata posttest pada kelas eksperimen dan kontrol sebesar 64,51 dan 56,94. Hal ini menunjukkan bahwa setelah diterapkan model pembelajaran inkuiri terbimbing pada kelas eksperimen mengalami peningkatan nilai rata-rata kemampuan berpikir kreatif

Peningkatan nilai kemampuan berpikir kreatif siswa pada materi materi momentum dan impuls diperoleh dari perhitungan nilai $\mathrm{N}$-Gain antara hasil pretest dan posttest pada kelas eksperimen dan kontrol dapat dilihat pada Tabel 2.

Tabel 2. Analisi N-Gain

\begin{tabular}{cclll} 
& Pre-Test & Post-test & N-Gain & Ket \\
\cline { 2 - 4 } Kelas & Mean & Mean & Mean & Sedang \\
\hline Eksperimen & 30,56 & 64,51 & 0,49 & Sedang \\
\hline Kontrol & 33,61 & 56,94 & 0,35 & \\
\hline
\end{tabular}

Berdasarkan data tersebut, diketahui peningkatan kemampuan berpikir kreatif siswa kelas eksperimen lebih besar dibandingkan kelas kontrol dengan $\mathrm{N}$-Gain sebesar 0,49 . Terdapat 5 indikator kemampuan berpikir kreatif yang digunakan dalam penelitian ini, perolehan peningkatan kemampuan berpikir kraetif siswa setiap indikator pada kelas eksperimen dan kontrol dapat dilihat pada tabel berikut

Tabel 3. Analisis $N$-Gain setiap indikator kelas eksperimen.

\begin{tabular}{lll} 
Indikator & $\begin{array}{l}\text { Eksperimen } \\
\mathbf{N} \text {-Gain }\end{array}$ & Kategori \\
\hline Fluency & 0,23 & Rendah \\
\hline Flexibility & 0,56 & Sedang \\
\hline Elaboration & 0,59 & Sedang \\
\hline Originalty & 0,49 & Sedang \\
\hline
\end{tabular}

Tabel 4. Analisis N-Gain setiap indikator kelas kontrol

\begin{tabular}{lll} 
Indikator & $\begin{array}{l}\text { Kontrol } \\
\mathbf{N} \text {-Gain }\end{array}$ & Kategori \\
\hline Fluency & 0,18 & Rendah \\
\hline Flexibility & 0,53 & Sedang \\
\hline Elaboration & 0,37 & Sedang \\
\hline Originalty & $-0,22$ & Rendah \\
\hline
\end{tabular}

Hasil uji normalitas data $\mathrm{N}$-Gain kelas eksperimen dan kontrol menggunakan metode Shapiro Wilk dengan bantuan software SPSS 23 for windows. Data terdistribusi dengan normal apabila nilai taraf sig lebih besar dari 0,05 . Berdasarkan hasil perhitungan pada kelas eksperimen dan kontrol menunjukkan

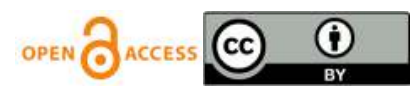


Efektifitas Model Pembelajaran...

bahwa nilai signifikansinya lebih besar dari 0,05 yaitu 0,894 pada kelas eksperimen dan 0,293 pada kelas kontrol. Sehingga dapat disimpulkan data $\mathrm{N}$-Gain pada kedua kelas terdistribusi dengan normal.

Hasil uji homogenitas data $N$-Gain menunjukkan signifikansinya lebih besar dari 0,05 yaitu 0,308. Hal ini menunjukkan bahwa nilai $\mathrm{N}$-Gain pada kedua kelas mempunyai varian yang sama (homogen). Berdasarkan uji normalitas dan uji homogenitas yang merupakan uji prsayarat untuk melakukan uji $t$ independen, diketahui bahwa data $\mathrm{N}$-Gain kelas eksperimen dan kontrol terdistrbusi secara normal dan homogen.

Uji hipotesis data $\mathrm{N}$-Gain selanjutnya digunakan uji $\mathrm{t}$ independen untuk mengetahui ada atau tidaknya perbedaan kemampuan berpikir kreatif siswa antara penggunaan model pembelajaran inkuiri terbimbing dengan model konvensional. Berdasarkan hasil perhitungan, nilai signifikan yang diperoleh lebih kecil dari 0,05 yaitu 0,000. Berdasarkan hasil tersebut dapat disimpulkan bahwa terdapat perbedaan yang signifikan pada peningkatan kemampuan berpikir kreatif siswa antara penggunaan model pembelajaran inkuiri terbimbing dengan model konvensional pada materi momentum dan impuls.

Uji effect size digunakan untuk mengetahui efektivitas model pembelajaran inkuiri terbimbing terhadap kemampuan berpikir kreatif siswa. Hasil perhitungan effect size pada kelas eksperimen dan kontrol dapat dilihat pada Tabel 5. Berdasarkan Tabel 5, dapat kita ketahui bahwa hasil uji effect size termasuk dalam kategori tinggi. Hal ini membuktikan bahwa model pembelajaran inkuiri terbimbing efektif untuk meningkatkan kemampuan berpikir kreatif siswa pada materi momentum dan impuls.

Tabel 5. Hasil uji effect size

\begin{tabular}{llll} 
Kelas & $\boldsymbol{N}$-Gain & Effect Size $(\boldsymbol{d})$ & Kategori \\
\hline Eksperimen & 0,49 & & \\
\hline Kontrol & 0,35 & 0,93 & tinggi
\end{tabular}

Hasil uji effect size tiap indikator kemampuan berpikir kreatif pada kelas eksperimen dan kontrol dapat kita lihat pada Tabel 6.

Tabel 6. Hasil uji effect size tiap indikator kemampuan berpikir kreatif

\begin{tabular}{|c|c|c|c|c|c|c|}
\hline \multirow{2}{*}{ Indikator } & \multicolumn{2}{|c|}{ Eksperimen } & \multicolumn{2}{|c|}{ Kontrol } & \multirow{2}{*}{$\begin{array}{l}\text { Effect } \\
\text { Size(d) }\end{array}$} & \multirow{2}{*}{ Kategor } \\
\hline & N-Gain & $S D$ & N-Gain & $S D$ & & \\
\hline Fluency & 0,23 & 0,21 & 0,18 & 0,25 & 0,22 & Sedang \\
\hline Flexibility & 0,56 & 0,23 & 0,53 & 0,19 & 0,14 & Rendah \\
\hline Elaboration & 0,59 & 0,29 & 0,37 & 0,27 & 0,78 & Sedang \\
\hline Originality & 0,49 & 0,46 & $-0,22$ & 0,91 & 0,98 & Tinggi \\
\hline
\end{tabular}

\section{PEMBAHASAN}

Penelitian ini bertujuan untuk mengetahui keefektifan model pembelajaran inkuiri terbimbing untuk meningkatkan kemampuan berpikir kreatif siswa kelas X MIPA. Sampel yang digunakan dalam penelitian ini yaitu siswa kelas X MIPA 4 dan 5 yang masing-masing berjumlah 36 siswa. Kelas eksperimen adalah kelas X MIPA 5 dan kelas kontrol adalah kelas X MIPA 4.

Pembelajaran inkuiri terbimbing merupakan suatu model yang dalam pelaksanaanya guru menyediakan bimbingan atau petunjuk cukup luas kepada peserta didik. Guru mempunyai peran aktif dalam menentukan permasalahan dan tahap-tahap pemecahannya. Terdapat 7 tahapan dalam model inkuiri terbimbing yaitu tahap identifikasi dan penetapan ruang lingkup masalah (inisiasi), tahap membuat hipotesis (seleksi), tahap merancang percobaan ( eksplorasi), tahap melakukan percobaan

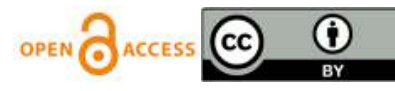


Efektifitas Model Pembelajaran...

untuk pengumpulan data/informasi (formulasi), tahap interpretasi data dan mengembangkan kesimpulan (koleksi), dan tahap mengkomunikasikan hasil percobaan (seleksi)

Pada kelas eksperimen dengan perlakuan model pembelajaran inkuiri terbimbing, siswa diberikan kesempatan untuk terlibat langsung dalam kegiatan pembelajaran sehingga siswa dapat menyelesaikan masalah yang ditemukan dan peserta didik dapat mengembangkan kemampuan berpikirnya melalui kegiatan pemecahan masalah salama proses pembelajaran. Sedangkan pada kelas kontrol dengan proses pembelajaran konvensional hanya berorientasi pada penguasaan sejumlah informasi atau konsep.

Berdasarkan hasil analisis data, dapat diketahui bahwa nilai rata-rata pretest kelas kontrol lebih tinggi dibandingkan dengan kelas eksperimen. Nilai berpikir kreatif siswa pada kelas kontrol dan kelas eksperimen sebelum diberikan perlakuan adalah masing-masing sebesar 33,61 dan 30,56. Setelah diberikan perlakuan yang berbeda pada kedua kelas, nilai rata-rata kelas eksperimen mengalami peningkatan yang lebih tinggi dibandingkan dengan kelas kontrol. Berdasarkan hasil yang telah didapatkan, maka kelas eksperimen mengalami peningkatan nilai rata-rata kemampuan berpikir kreatif setelah diterapkan model pembelajaran inkuiri terbimbing.

Peningkatan kemampuan berpikir kreatif siswa dianalisis dengan menggunakan $\mathrm{N}$-Gain. Berdasarkan Tabel 2 terdapat perbedaan nilai $\mathrm{N}$-Gain antara kelas eksperimen dan kontrol yang diperoleh dari data pretest dan posttest. Pada kelas eksperimen diperoleh $\mathrm{N}$-Gain sebesar 0,49 dengan kriteria sedang. Sedangkan pada kelas kontrol diperoleh $\mathrm{N}$-Gain sebesar 0,35 . Hal ini menunjukkan bahwa penerapan model pembelajaran inkuiri terbimbing pada kelas eksperimen dapat meningkatkan kemampuan berpikir kreatif siswa sebesar $49 \%$. Hasil penelitian ini sejalan dengan penelitian yang dilakukan oleh Syech Thoyiba Qodratullah (2019) yang menunjukkan hasil bahwa peningkatan kemampuan berpikir kreatif siswa diajarkan dengan model inkuiri terbimbing lebih tinggi dari pada siswa yang diajarkan dengan model konvensional dengan pembuktian hasil yang signifikan. Pada kelas eksperimen, peningkatan kemampuan berpikir kreatif siswa lebih tinggi dari pada kelas kontrol. Hal ini disebabkan karena pada kelas eksperimen dengan perlakuan model pembelajaran inkuiri terbimbing, siswa diberikan kesempatan untuk terlibat langsung dalam kegiatan pembelajaran sehingga siswa dapat menyelesaikan masalah yang ditemukan dan peserta didik dapat mengembangkan kemampuan berpikirnya melalui kegiatan pemecahan masalah salama proses pembelajaran. Sedangkan pada kelas kontrol dengan proses pembelajaran konvensional hanya berorientasi pada penguasaan sejumlah informasi atau konsep.

Berdasarkan Tabel 3 dan 4, kategori perolehan nilai $\mathrm{N}$-Gain setiap indikator kemampuan berpikir kreatif pada kelas eksperimen mengalami peningkatan yang lebih besar dibandingkan dengan kelas control, meskipun kedua kelas tersebut hanya berada dalam kategori sedang dan rendah. Indikator fluency pada kelas eksperimen maupun kontrol sama-sama memperoleh $\mathrm{N}$-Gain yang termasuk dalam kategori rendah yaitu masing-masing 0,23 dan 0,18 . Artinya peningkatan yang diperoleh siswa masingmasing sebesar $23 \%$ dan $18 \%$. Rendahnya hasil indikator fluency menunjukkan bahwa siswa belum bias mengungkapkan gagasan secara lancar, dan belum bisa memberikan banyak gagasan atau ide pada waktu yang ditentukan. Hasil analisis indikator fluency peserta didik masih lemah dalam mengemukakan berbagai rencana dan kurang memahami maksud pertanyaan dan gambar yang disajikan. Hasil ini sejalan dengan dengan penelitian yang dilakukan oleh Pratiwi Indiraningrum (2018) yang menunjukkan indicator fluency berada dalam kategori rendah dengan persentase sebesar $25 \%$. Menurut Munandar (2004) perilaku siswa yang menunjukkan kemampuan berpikir lancar (fluency) adalah siswa yang mengajukan banyak pertanyaan, menjawab dengan sejumlah jawaban, dan lancar mengungkapkan gagasan-gagasan

Indikator flexibility kelas eksperimen memperoleh $\mathrm{N}$-Gain sebesar 0,56 . Sedangkan kelas kontrol memperoleh $\mathrm{N}$-Gain sebesar 0,53 . Artinya peningkatan yang diperoleh kelas eksperimen dan kontrol sama-sama dalam kategori sedang. Meskipun demikian perolehan $\mathrm{N}$-Gain yang diperoleh pada kelas eksperimen tetap lebih tinggi, artinya mengalami peningkatan yang lebih tinggi, yaitu sebesar $56 \%$. Hasil ini sejalan dengan penelitian yang dilakukan oleh Riswan (2018) yang menunjukkan peningkatan

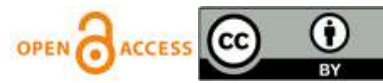


Efektifitas Model Pembelajaran...

indikator flexibility berada dalam kategori sedang dengan persentase $58,10 \%$. Selain itu juga sejalan dengan penelitian Dian (2018) yang menunjukkan indikator flexibility mengalami peningkatan yang berada dalam kriteria kreatif. Berdasarkan hal tersebut dapat disimpulkan bahwa model inkuiri terbimbing yang diterapkan pada kelas eksperimen lebih mampu menghasilkan gagasan, jawaban, dan keluwesan berpikir siswa.

Indikator elaboration pada kelas eksperimen maupun kelas kontrol sama-sama memperoleh $\mathrm{N}$-Gain yang termasuk dalam kategori sedang, yaitu masing-masing 0,59 dan 0,37 . Perolehan $N$-Gain pada kelas eksperimen tetap lebih tinggi dari pada kelas kontrol meskipun sama-sama berada pada kategori sedang dengan peningkatan yang mencapai $59 \%$. Hasil penelitian ini relevan dengan penelitian yang dilakukan oleh Riswan (2018) yang menunjukkan indikator elaboration dengan persentase sebesar $52,86 \%$. Dengan penerapan model inkuiri terbimbing pada kelas eksperimen peserta didik diajarkan untuk menjawab atau menyelesaikan masalah dengan melakukan langkah-langkah yang rinci, mencoba mengembangkan dan memperoleh gagasan dalam penyelesaian masalah secara terperinci.

Indikator originality kelas eksperimen memperoleh $\mathrm{N}$-Gain sebesar 0,49. Artinya peningkatan yang diperoleh siswa sebesar $49 \%$ yang termasuk dalam kategori sedang. Hal ini sejalan dengan penelitian yang dilakukan oleh Arifah (2016) yang menunjukkan peningkatan indikator originality berada dalam kategori sedang. Sedangkan kelas kontrol memperoleh $\mathrm{N}$-Gain yang termasuk dalam kategori rendah yaitu sebesar $-0,22$. Melalui model inkuiri terbimbing pada kelas eksperimen dapat menumbuhkan kemampuan berpikir kreatif siswa pada indikator originality. Hal ini dikarenakan pembelajaran pada kelas eksperimen dengan tahapan pembelajaran seperti merumuskan kesimpulan dapat melatih siswa memberikan penjelasan sederhana terkait dengan permasalahan yang diberikan. Siswa pada kelas kontrol sudah bisa menjawab pertanyaan, tetapi belum mampu untuk menjawabnya sesuai dengan yang diharapkan, dan siswa masih kesulitan dalam mengungkapkan bermacam-macam gagasan atau ide yang benar-benar asli dari dalam dirinya dalam menyelesaikan suatu permasalahan.

Analisis data berikutnya adalah uji hipotesis, dimana sebelum dilakukan uji beda terdapat dua buah uji prsayarat yang perlu dicari, yaitu uji normalitas dan homogenitas. Berdasarkan hasil analisis data, di tunjukkan bahwa nilai sig. lebih besar dari 0,05, yaitu sebesar 0,894 dan 0,293. Hal ini menunjukkan bahwa data antara kelas eksperimen dan kontrol terdistribusi dengan normal. Berdasarkan hasil analisis data uji homogenitas untuk keseluruhan kemampuan berpikir kreatif pada kelas eksperimen dan control, diperoleh nilai sig. lebih besar dari 0,05 yaitu 0,308. Berdasarkan hal tersebut, data untuk keseluruhan kemampuan berpikir kreatif siswa pada kelas eksperimen dan kontrol memiliki nilai varian yang sama (homogen). Berdasarkan hasil dari uji normalitas dan homogenitas data. Diketahui bahwa data untuk keseluruhan berpikir kreatif siswa kelas eksperimen dan kontrol terdistribusi secara normal dan homogen. Oleh karena itu, uji hipotesis selanjutnya adalah menggunakan uji $t$ independen. Uji $t$ independen ini dilakukan untuk mengetahui ada atau tidaknya perbedaan peningkatan kemampuan berpikir kreatif dengan diterapkan model inkuiri terbimbing dan konvensional. Berdasarkan hasil analisis data, diperoleh nilai sig. sebesar 0,000, lebih kecil dari 0,05. Hal ini dapat disimpulkan bahwa terdapat perbedaan secara signifikan pada kemampuan berpikir kreatif siswa antara dua kelas yang menerapkan model inkuri terbimbing dengan model konvensional pada materi momentum dan impuls. Hasil penelitian ini sejalan dengan penelitian yang dilakukan oleh Sulastri (2019) yang menunjukkan hasil yang sama dari penelitiannya.

Untuk mengetahui tingkat keefektifan penerapan model pembelajaran inkuiri terbimbing dalam peningkatan kemampuan berpikir kreatif siswa, peneliti menggunakan uji effect size. Tabel 5 menyajikan hasil uji effect size kelas eksperimen dan kontrol, tabel tersebut menunjukkan hasil sebesar 0,93 yang termasuk dalam kategori tinggi. Hal ini dapat disimpulkan bahwa model pembelajaran inkuiri terbimbing efektif untuk meningkatkan kemampuan berpikir kreatif siswa pada materi momentum dan impuls.

Tabel 6 memperlihatkan perhitungan effect size untuk tiap indicator kemampuan berpikir kreatif. Pada indikator flexibility diperoleh effect size sebesar 0,14 dengan kategori rendah. Hasil ini

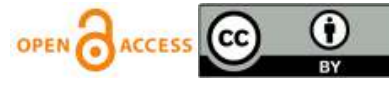


Efektifitas Model Pembelajaran...

menunjukkan bahwa model pembelajaran inkuiri terbimbing tidak memiliki keefektifan untuk meningkatkan indikator flexibility. Indikator fluency, elaboration, dan original masing-masing diperoleh effect size sebesar 0,22, 0,78 dan 0,98. Hal ini menunjukkan bahwa model inkuiri terbimbing termasuk efektif untuk meningkatkan indikator fluency, elaboration, dan original. Berdasarkan hasil uji effect size tiap indikator kemampuan berpikir kreatif, dapat disimpulkan bahwa tidak semua indikator dapat dicapai dengan baik secara bersamaan, namun menyisakan satu indikator yang peningkatannya masih dalam kategori rendah.

Hasil efektivitas yang diperoleh tidak terlalu memuaskan khususnya pada indikator flexibility. Hal ini dapat dikarenakan beberapa kendala yang terjadi selama proses penelitian. Kendala yang dimaksud adalah ketika berlangsungnya kegiatan pembelajaran dengan menggunakan model pembelajaran inkuiri terbimbing pada kelas eksperimen, siswa belum terbiasa belajar dengan model inkuiri terbimbing dalam menyelesaikan permasalahan yang diberikan oleh guru. Hal ini disebabkan karena siswa sudah terbiasa dengan model pembelajaran konvensional yang mana siswa terbiasa hanya mendapat penjelasaan dari guru untuk memahami konsep materi pelajaran. Kemudian siswa juga belum terbiasa menggunakan alat dan bahan dalam kegiatan praktikum, sehingga peneliti diharapkan dapat mengatasinya dengan membimbing siswa dalam kegiatan praktikum.

\section{PENUTUP}

Berdasarkan penelitian yang telah dilakukan dan analisis data yang telah dipaparkan terkait keefektifan model inkuiri terbimbing untuk meningkatkan kemampuan berpikir kreatif siswa SMA pada materi momentum dan impuls, dapat disimpulkan bahwa kemampuan berpikir kreatif siswa SMA pada materi momentum dan impuls dapat ditingkatkan dengan menerapkan model pembelajaran inkuiri terbimbing. Kemampuan berpikir kreatif siswa pada kelas eksperimen mengalami peningkatan dengan kategori sedang, yang ditunjukkan dengan hasil $N$-Gain sebesar 0,49 . Sedangkan keefektifan model pembelajaran inkuiri terbimbing untuk meningkatkan kemampuan berpikir kreatif siswa SMA pada materi momentum dan impuls berada dalam kategori tinggi, yang ditunjukkan oleh hasil uji effect size sebesar 0,93.

Adapun saran yang dapat diberikan berdasarkan penelitian yang telah dilakukan yaitu penulis mengharapkan adanya penelitian lebih lanjut yang berfokus pada peningkatan indikator flexibility. Hal tersebut dapat dilakukan dengan cara memberikan pertanyaan-pertanyaan yang dapat membangun kemampuan siswa untuk memberikan jawaban yang benar lebih dari satu dengan cara yang berbeda, dan juga dengan memperbanyak soal pretest dan posttest untuk indikator flexibility yang dapat mendorong siswa untuk berpikir lebih luwes.

\section{DAFTAR PUSTAKA}

Aftriani, D, N., dkk. 2019. Pengaruh Pembelajaran Pembelajaran Inkuiri Terbimbing Pada Pelajaran Kimia Terhadap Kemampuan Berpikir Kreatif Siswa. Chemistry Education Practice, 1 (2), 1-6

Amijaya S.L, Ramdani A dan Merta W. 2018. "Pengaruh Pembelajaran Inkuiri Terbimbing Terhadap Hasil Belajar dan Kemampuan Berpikir Kritis Peserta Didik". Jurnal Pijar Mipa. Vol,2 No.02

Depdiknas. 2005. Misi Pendidikan Nasional dalam Undang-Undang Nomor 20 Tahun 2003, Jakarta: Depdiknas

Fraenkel, Jack R. 2012. How To Design and Evaluate Research in Education. America: McGraw-Hill.

Maulidah,E. 2019. Character Building dan Keterampilan Abad 21 dalam Pembelajaran di Era Revolusi Industri 4.0. In Prosiding Seminar Nasional PGSD UST

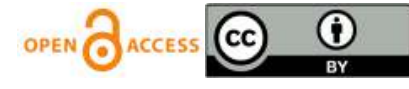


Efektifitas Model Pembelajaran...

Munandar, U. 2004. Pengembangan Kreativitas Anak Berbakat. Jakarta: PT. Rineka Cipta

Nur, H dan Mohammad J. 2014. Strategi Belajar- Mengajar dikelas. Jakarta: Prestasi Pustaka

Nurdyansyah dan Eni F. 2016. Inovasi Model Pembelajaran.

Purwananti, Y. S. 2016. Peningkatan Kualitas Pendidikan sebagai Pencetak Sumber Daya Manusia Handal. Proceding International Seminar FoE (Faculty of Education).

Pratiwi, I., dkk. 2018. Kemampuan Berpikir Kreatif Matematika Siswa MTs Di Tinjau Dari Kemampuan Resiliensi Matematika Siswa. Jurnal Pembelajaran Matematika Inovatif. 1 (1) pp 171-183

Redhana, I. W. 2019. Mengembangkan Keterampilan Abad Ke-21 Dalam Pembelajaran Kimia. Jurnal Pendidikan Kimia. 1(13) 2239-2251

Riswan. 2018. Kemampuan Berpikir Kreatif Siswa dalam Kegiatan Praktikum Biologi Pada Siswa Kelas XI. Artikel ilmiah. 1-13

Sulastri, F., dkk. 2019. Pengaruh Penerapan Model Pembelajaran Inkuiri Terbimbing (Guided Inquiry) Berbantuan Lembar Kerja Siswa Terhadap Kemampuan Berpikir Kreatif Siswa. 3(1), 15-22

Suardipa, I. P. 2019. Kajian Creative Thingking Matematis Dalam Inovasi. 3(2), 15- 22

Wenning, C. J., (2007). Assessing inquiry skills as a component of scientific literacy. Journal of Physic Teacher Education

Wenning, C. J., 2011. Level Inquiry: Hierarchies of Pedagogical Practices and Inquiry Processes. Journal of Physics Teacher Education

Yuliani, H., dkk. 2017. Keterampilan Berpikir Kreatif Pada Siswa Sekolah Menengah Di Palangkaraya Menggunakan Pendekatan Saintifik." Jurnal Pendidikan Fisika dan Keilmuan (JPFK). 3(1), 49-51. https://doi.org/10.25273/jpfk.v3i1.1134 